\title{
Evaluation of Developmental Competence of In Vitro-produced Porcine Embryos Based on the Timing, Pattern and Evenness of the First Cleavage and Onset of the Second Cleavage
}

\author{
Thanh Quang DANG-NGUYEN ${ }^{1-3)}$, Kazuhiro KIKUCHI ${ }^{1)}$, Tamas SOMFAI ${ }^{1,2}$, \\ Manabu OZAWA ${ }^{1}$, Michiko NAKAI ${ }^{1)}$, Naoki MAEDOMARI ${ }^{1)}$, Nguyen VIET-LINH $^{1,4}$, \\ Yukio KANAI ${ }^{3)}$, Bui Xuan NGUYEN ${ }^{5)}$ and Takashi NAGAI ${ }^{2)}$ \\ ${ }^{1)}$ Department of Animal Science, National Institute of Agrobiological Sciences, Ibaraki 305-8602, ${ }^{2)}$ Department of Animal \\ Breeding and Reproduction, National Institute of Livestock and Grassland Science, Ibaraki 305-0901, 3) Graduate School of \\ Life and Environmental Sciences, University of Tsukuba, Ibaraki 305-8577, ${ }^{4}$ Graduate School of Agricultural and Life \\ Sciences, University of Tokyo, Ibaraki 319-0206, Japan and ${ }^{5)}$ Laboratory of Embryo Technology, Institute of Biotechnology, \\ Vietnamese Academy of Science and Technology, Hanoi, Vietnam
}

\begin{abstract}
The following selection markers for in vitro-produced porcine embryos were investigated: the timing, pattern and evenness of the first cleavage and the timing of the second cleavage. The embryos that cleaved by $30 \mathrm{~h}$ postinsemination (hpi) developed to blastocysts at a significantly higher rate $(60.9 \%)$ and with a significantly higher cell number (33.6 cells) than those of embryos cleaved by $36 \mathrm{hpi}(26.4 \%$ and 23.6 cells, respectively, P<0.05). Blastocyst proportions derived from 2- and 3-cell embryos cleaved by 30 hpi (68.2 and 65.3\%, respectively) were significantly higher than those of 4 - and $>4$-cell embryos ( 46.3 and $42.6 \%$, respectively, $\mathrm{P}<0.05$ ). The cell number per blastocyst generated from 2-cell embryos was significantly greater (37.3 cells) than those from 3-, 4- and >4-cell embryos (23.6-27.8 cells, $\mathrm{P}<0.05)$. Among embryos cleaved by $30 \mathrm{hpi}$, the blastocysts derived from evenly cleaved embryos (40.6 cells) were of significantly better quality than those derived from unevenly cleaved embryos $(33.2$ cells, $\mathrm{P}<0.05)$, although their blastocyst rates did not differ. The evenly cleaved embryos that underwent subsequent cleavage within $18 \mathrm{~h}$ had significantly higher blastocyst rates (72.7-81.0\%) and quality (36.2-40.9 cells) than those without subsequent cleavage $(48.3 \%$ and 22.5 cells, respectively, $\mathrm{P}<0.05)$ during the same period. In conclusion, the timing, pattern and evenness of the first cleavage and the timing of the second cleavage affected the developmental competence and quality of in vitroproduced porcine embryos.
\end{abstract}

Key words: Cell division, Early stage, Embryo morphology, In vitro fertilization, Pig

(J. Reprod. Dev. 56: 593-600, 2010)

$\mathbf{T}$ he developmental competence of porcine embryos produced in vitro after in vitro maturation (IVM), fertilization (IVF) and culture (IVC) for a short period has been confirmed [1, 2]. Birth of piglets has been accomplished from IVM-IVF embryos after IVC to the 2- to 4-cell stages [3-5] or 8-cell to morula stage [6]. Although transfer of in vitro-produced (IVP) blastocysts has also led to pregnancies and live births [7-9], utilization of early IVP embryos for transfer remains preferable because the viability of IVP porcine embryos is decreased by IVC after IVF [10]. High oxygen tension, imperfect culture media and polyspermy are thought to reduce the developmental competence of IVP porcine embryos [11]. Thus, large numbers of early-stage IVP embryos should be transferred to recipients to ensure multiple pregnancies.

For the success of embryo transfer (ET) programs, selection of high-quality embryos for ET and elimination of those with low developmental competence at early stages are key factors [12, 13]. To achieve this goal, transfer of cleavage stage embryos chosen by

Received: March 11, 2010

Accepted: June17, 2010

Published online in J-STAGE: July 20, 2010

(C)2010 by the Society for Reproduction and Development

Correspondence: K Kikuchi (e-mail: kiku@affrc.go.jp) an effective embryo selection system is necessary. The timing of the first cleavage and cleavage evenness are among the most frequently used morphological criteria for choosing good quality embryos for ET. Studies in cattle [14], humans [15], mice [16] and pigs $[13,17]$ have shown that the timing of first cleavage has a great influence on potential for development to blastocysts. Morphological assessment of human [18, 19] and porcine embryos [17] at an early stage has shown that there are many variations in blastomere number, fragmentation, blastomere size, cleavage symmetry and mono nuclearity; these factors affect the implantation and pregnancy rates. These studies have also suggested that, when scoring embryos for embryo transfer, blastomere size is of more importance than slight fragmentation, since fragmentation of less than $15 \%$ can disappear during further embryo development.

The developmental stage, in other words, cell stage, of embryos at any given time is thought to be linked to embryo viability and chromosomal abnormalities. In hamsters, 8-cell embryos obtained after culture for $58 \mathrm{~h}$ had greater ability to develop to the blastocyst stage than 4-cell embryos obtained after the same culture period [20]. Moreover, morulae and blastocysts derived from 4-cell embryos were less viable than those from 8-cell embryos. In pigs, in vitro-produced 3- or 4- and 5- to 8-cell embryos selected at $52 \mathrm{~h}$ 
post-insemination (hpi) showed greater potential to develop to blastocysts than embryos at the 2- and $>8$-cell stages [21]. In the same report, it was also reported that blastocysts derived from 3- or 4and 5- to 8-cell embryos had a lower incidence of chromosomal abnormalities. On the other hand, an abnormal cleavage pattern may occur during the first embryonic cleavage, resulting in embryos with 3 or 4 blastomeres and abnormal chromosome numbers [22, 23]. Selection of embryos with large blastomere numbers at an early developmental stage may therefore lead to contraselection of embryos with impaired developmental competence. Although the importance of the timing of the first cleavage and embryo morphology of IVP porcine embryos as selection markers has been confirmed [13], their effect on blastocyst quality has not reported yet. Also, the influence of cleavage pattern, cleavage evenness and the timing of subsequent cleavages have not been studied substantially in this species in vitro.

Here, we investigated the effects of the timing of the first cleavage, number of blastomeres and their nuclear status after the first cleavage, cleavage evenness and the timing of the subsequent embryonic cleavages on the developmental competence of IVP porcine embryos.

\section{Materials and Methods}

\section{Oocyte collection and in vitro maturation}

Ovaries were collected from prepubertal crossbred gilts (Landrace $\times$ Large White) at a local slaughterhouse and transported within $1 \mathrm{~h}$ to the laboratory in Dulbecco's phosphate-buffered saline (Nissui Pharmaceutical, Tokyo, Japan) at about 35 C. Cumulus-oocyte complexes (COCs) were collected by scraping of 3- to 6-mm follicles in Medium 199 (with Hanks' salts; Sigma-Aldrich Chemical, St. Louis, MO, USA) supplemented with 5\% (v/v) fetal calf serum (Gibco, Life Technologies, Carlsbad, CA, USA), 20 mM HEPES (Dojindo Laboratories, Kumamoto, Japan), 100 U/ml penicillin $\mathrm{G}$ potassium (Sigma) and $0.1 \mathrm{mg} / \mathrm{ml}$ streptomycin sulfate (Sigma). Groups of about 40 to 50 COCs were then cultured for 22 $\mathrm{h}$ in $500 \mu \mathrm{l}$ of modified North Carolina State University (NCSU)37 medium [24] containing 10\% (v/v) porcine follicular fluid, 0.6 mM cysteine, $50 \mathrm{mM} \beta$-mercaptoethanol, $1 \mathrm{mM}$ dibutyryl cAMP (dbcAMP), 10 IU/ml eCG (Serotropin; ASKA Pharmaceutical, Tokyo, Japan) and 10 IU/ml hCG (500 units; Puberogen, Novartis Animal Health, Tokyo, Japan). They were then cultured for a further $24 \mathrm{~h}$ in the maturation medium without the dbcAMP and hormones. Maturation of oocytes was performed in 4-well dishes (Nunclon Multidishes, Thermo Fisher Scientific, Roskilde, Denmark) in an atmosphere of $5 \% \mathrm{CO}_{2}, 5 \% \mathrm{O}_{2}$ and $90 \% \mathrm{~N}_{2}$ at $39 \mathrm{C}$. Porcine follicular fluid was prepared in advance by aspiration with a syringe and centrifuged at $1,600 \times g$ for $90 \mathrm{~min}$ at $4 \mathrm{C}$. The supernatant was collected and stored at $-20 \mathrm{C}$. A certain volume (about $2 \mathrm{l}$ ) of the stock was then thawed, mixed and centrifuged again as described above, sorted in $10 \mathrm{ml}$ aliquots and stored at $-20 \mathrm{C}$ as a single batch until use.

\section{In vitro fertilization}

The medium for IVF was a modified Pig-FM [25] supplemented

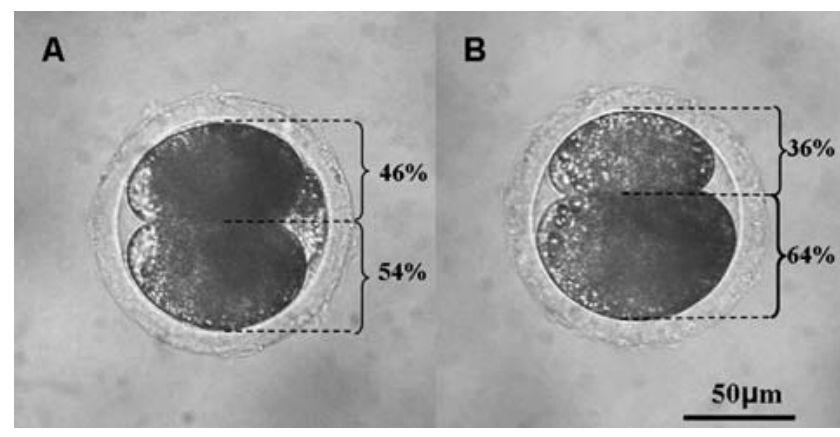

Fig. 1. Categories of evenly (A) and unevenly cleaved 2-cell (B) embryos according to size correlation between 2 blastomeres. Both photographs were taken with a phase-contrast microscope at the same magnification.

with $2 \mathrm{mM}$ caffeine and $5 \mathrm{mg} / \mathrm{ml}$ bovine serum albumin (BSA; Fraction V, Sigma). IVF was conducted according to the method reported by Kikuchi et al. [8]. Briefly, after $46 \mathrm{~h}$ of maturation, COCs were transferred into $100-\mu l$ droplets of fertilization medium covered by mineral oil. About 20 oocytes per $100 \mu$ medium were fertilized by epididymal spermatozoa obtained from a Landrace boar and frozen-thawed [26] and preincubated at $37 \mathrm{C}$ for $15 \mathrm{~min}$ [27]. The final concentration of spermatozoa was $1 \times 10^{5} / \mathrm{ml}$. IVF oocytes and spermatozoa were cocultured for $3 \mathrm{~h}$ at $38.5 \mathrm{C}$ under $5 \% \mathrm{O}_{2}$. The day of IVF was defined as Day 0 .

\section{In vitro culture}

After co-incubation of gametes, cumulus cells and attached spermatozoa were removed from the oocytes by gentle pipetting through a fine glass pipette. They were then transferred into IVC medium. Two types of IVC medium were prepared [8]. The basic IVC medium was NCSU-37 modified by the addition of $0.4 \%$ (w/ v) BSA and $50 \mu \mathrm{M} \beta$-mercaptoethanol. Embryos were cultured at 38.5 C in IVC-PyrLac (basic IVC medium with the addition of 0.17 $\mathrm{mM}$ sodium pyruvate and $2.73 \mathrm{mM}$ sodium lactate) from Day 0 (the day of IVF was defined as Day 0) to Day 2 and in IVC-Glu (basic medium supplemented with $5.55 \mathrm{mM}$ glucose) until Day 6 .

\section{Evaluation of cleavage pattern and cleavage evenness}

Cultured embryos were evaluated for cleaved status and developmental stage under a stereomicroscope with $\times 10$ to $\times 130$ magnification (Olympus SZX12, Tokyo, Japan). In a preliminary experiment, all 2-cell embryos were collected and photographed. The evenness of the 2-cell embryos was determined by analyzing the photos using ImageJ (Ver. 1.42, National Institute of Health). Evenly cleaved 2-cell embryos were defined as 2-cell embryos in which the smaller blastomeres occupied $45-50 \%$ of the total surface area (Fig. 1A). Unevenly cleaved 2-cell embryos were defined as 2-cell embryos in which the smaller blastomeres occupied $44 \%$ of the total surface area (Fig. 1B). The selection and determination thereafter were performed under a stereomicroscope equipped with a micrometer. 
Nuclear staining and evaluation of nuclear status of embryos

To evaluate the nuclear status of cleaved embryos and the total number of cells in blastocysts, embryos were mounted on glass slides and fixed with acetic acid:ethanol (1:3) for at least 3 days, then stained with $1 \%(\mathrm{w} / \mathrm{v})$ orcein in acetic acid, mounted in glycerol:acetic acid:water (1:1:3) and examined under a phase-contrast microscope with $\times 100$ to $\times 400$ magnification (Olympus BX51). At $30 \mathrm{~h}$ of IVC, the embryos containing one nucleus in each blastomere were considered to have a normal nuclear status. The abnormal embryos had at least one blastomere without a nucleus or with multiple nuclei. Total cell numbers in blastocysts were counted at least 3 times after nuclear staining as described above, and the average numbers were analyzed.

\section{Experimental design}

Experiment 1: To evaluate the onset of the first cleavage in our IVP system, the number of newly cleaved embryos was recorded at $20,24,30,36,42$ and 48 hpi by examination under a stereomicroscope.

Experiment 2: To investigate whether the timing of first cleavage had any effect on the developmental competence of embryos, newly cleaved embryos were selected at 30, 36, 42 and 48 hpi. They were then cultured separately and examined on Day 6 for blastocyst formation and total number of cells in blastocysts. An embryo with a blastocoel and more than 10 cells was defined as a blastocyst.

Experiment 3: The relationship between cleavage patterns of embryos and their ability to develop to the blastocyst stage were determined. Newly cleaved embryos were selected at 30 hpi and categorized into groups. Embryos with 2, 3, 4 and $>4$ blastomeres were classified as 2-, 3-, 4- and >4-cell embryos, respectively. Approximately half of the embryos from each group were fixed and examined for nuclear status, whereas others were cultured in vitro until Day 6 to examine their developmental competence.

Experiment 4: We examined the effects of cleavage evenness of 2-cell embryos on their further development. The 2-cell embryos were collected at $30 \mathrm{hpi}$ and categorized into 2 groups, 1) evenly cleaved and 2) unevenly cleaved, on the basis of the size of one blastomere relative to the other as mentioned above. Evenly and unevenly cleaved embryos were then cultured separately until Day 6 and examined for embryonic development to the blastocyst stage.

Experiment 5: The effect of the timing of the second cleavage on developmental competence of embryos was examined. Evenly cleaved 2-cell embryos collected by 30 hpi were harvested and subsequently cultured. These embryos were further observed consecutively 3 times (36, 42 and $48 \mathrm{hpi}$ ) to record the onset of cleavages subsequent to the 30 -h one $(6+, 12+$ and $18+$ groups, respectively) or lack of cleavage (18- group). The embryos were further cultured in vitro until Day 6 and then examined for embryonic development to the blastocyst stage.

\section{Statistical analysis}

Data on the proportion of embryos with a normal cleavage pattern, blastocyst formation rate and total number of cells in blastocysts were analyzed by one-way ANOVA followed by Tukey's test. Percentage data were arcsine transformed before
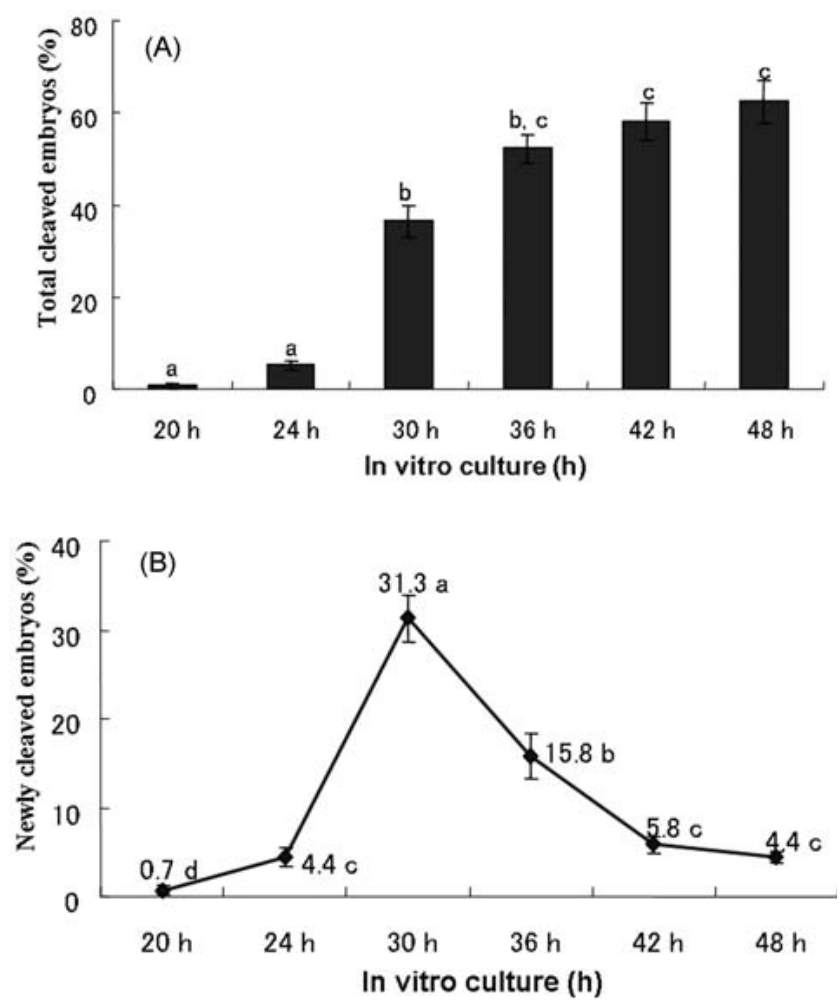

Fig. 2. The proportion of total cleaved (A) and newly cleaved (B) embryos at different times during in vitro culture of porcine oocytes matured and fertilized in vitro. The number of newly cleaved embryos was recorded at 20, 24, 30, 36, 42 and 48 h, and their mean percentages \pm SEM of the total cleaved embryos are presented. A total of 872 embryos were evaluated in this assay. Values with different superscripts are significantly different $(\mathrm{P}<0.05)$. Three replicated trials were carried out.

analysis. Data are expressed as means \pm SEM.

\section{Results}

\section{Experiment 1}

Data for the timing of the first cleavage are shown in Fig. 2. The proportions of cleaved embryos recorded at 20 and 24 hpi were 0.7 \pm 0.5 and $4.4 \pm 1.1 \%$, respectively. A rapid rise in the rate of cleaved embryos was observed at $30 \mathrm{hpi}$, at which time $31.3 \%$ of embryos were newly cleaved, raising the total percentage of cleaved embryos to $36.4 \pm 3.1 \%$ (Fig. 2A). The percentage of newly cleaved embryos gradually decreased thereafter (Fig. 2B). The total percentage of cleaved embryos by 36 hpi was $52.2 \pm$ $3.1 \%$, and that by $42 \mathrm{hpi}$ was $58.0 \pm 4.0 \%$. By $48 \mathrm{hpi}$, a total of $62.4 \%$ of embryos had undergone first cleavage (Fig. 2A). Therefore, in experiment 2, cleaved embryos were collected at $30 \mathrm{hpi}$ and then at 36, 42 and 48 hpi.

\section{Experiment 2}

The relationships between the timing of first cleavage and development to the blastocyst stage are shown in Table 1 . The 
Table 1. Developmental competence of in vitro matured and fertilized porcine oocytes cleaved at different times

\begin{tabular}{cccc}
\hline $\begin{array}{c}\text { Timing of 1st } \\
\text { cleavage (hpi) }\end{array}$ & $\begin{array}{c}\text { No. of embryos } \\
\text { examined }\end{array}$ & Blastocysts (\%) & $\begin{array}{c}\text { Total no. of cells } \\
\text { in blastocysts }\end{array}$ \\
\hline 30 & 348 & $212(60.9 \pm 5.7)^{\mathrm{a}}$ & $33.6 \pm 1.4^{\mathrm{a}}$ \\
36 & 208 & $55(26.4 \pm 3.7)^{\mathrm{b}}$ & $23.6 \pm 1.8^{\mathrm{b}}$ \\
42 & 80 & 0 & - \\
48 & 69 & 0 & - \\
$\mathrm{N}^{\mathrm{d}}$ & 984 & $15(1.5 \pm 0.4)^{\mathrm{c}}$ & $17.3 \pm 2.1^{\mathrm{b}}$ \\
\hline
\end{tabular}

a, b, c Values with different superscripts within a column are significantly different $(\mathrm{P}<0.05) . \quad{ }^{\mathrm{d}} \mathrm{N}$ : Embryos did not cleave by $48 \mathrm{~h}$ post IVF. Five replicated trials were carried out. hpi: hours post-insemination.

Table 2. Nuclear status of in vitro produced porcine embryos with different blastomere numbers at $30 \mathrm{hpi}$

\begin{tabular}{ccc}
\hline No. of blastomeres $^{\mathrm{e}}$ & No. of embryos examined & Embryos with normal nuclear status (\%) \\
\hline 2-cell & 163 & $157(96.3 \pm 1.6)^{\mathrm{a}}$ \\
3-cell & 49 & $6(12.2 \pm 5.3)^{\mathrm{b}}$ \\
4-cell & 36 & $19(52.8 \pm 23.4)^{\mathrm{c}}$ \\
$>$ 4-cell & 24 & $6(25.0 \pm 12.4)^{\mathrm{d}}$ \\
\hline
\end{tabular}

e Selected from $30 \mathrm{~h}$ post-insemination (hpi) onward. ${ }^{\mathrm{a}-\mathrm{d}}$ Values with different superscripts within a column are significantly different $(\mathrm{P}<0.05)$. The embryos in which each blastomere contained one nucleus were considered to have a normal nuclear status. The abnormal embryos had at least one blastomere without a nucleus or with more than one nucleus. Three replicated trials were carried out.

Table 3. Development of in vitro produced porcine embryos with different blastomere numbers at 30 hpi to the blastocyst stage

\begin{tabular}{cccc}
\hline Embryo & No. of embryos examined & Blastocyst (\%) & Total no. of cells in blastocysts \\
\hline 2-cell & 198 & $135(68.2 \pm 6.3)^{\mathrm{a}}$ & $37.3 \pm 1.9^{\mathrm{a}}$ \\
3-cell & 49 & $32(65.3 \pm 7.7)^{\mathrm{a}}$ & $27.8 \pm 2.7^{\mathrm{b}}$ \\
4-cell & 54 & $25(46.3 \pm 11.4)^{\mathrm{b}}$ & $29.4 \pm 5.0^{\mathrm{b}}$ \\
$>$ 4-cell & 47 & $20(42.6 \pm 6.3)^{\mathrm{b}}$ & $23.6 \pm 2.8^{\mathrm{b}}$ \\
\hline
\end{tabular}

a, b Values with different superscripts within a column are significantly different $(\mathrm{P}<0.05)$. Five replicated trials were carried out. hpi: h post-insemination.

proportion of embryos cleaved by 30 hpi (30 h-cleaved embryos) that developed to blastocysts (60.9 $\pm 5.7 \%)$ was significantly higher than that of embryos cleaved by 36 hpi (26.4 $\pm 3.7 \%)$. The number of cells in blastocysts derived from embryos cleaved by 30 hpi $(33.6 \pm 1.4)$ was significantly higher than that of those cleaved by $36 \mathrm{hpi}(23.6 \pm 1.8)$. On the other hand, embryos in which cleavage occurred by 42 or 48 hpi did not develop to the blastocyst stage. Embryos that had not cleaved by 48 hpi showed very low capacity to develop to the blastocyst stage $(1.5 \pm 10.4 \%)$ and were of poor quality $(17.3 \pm 2.1$ cells $)$.

\section{Experiment 3}

The cleavage status (number of blastomeres) of the embryos and their nuclear status after fixation and staining are shown in Table 2. Almost all 2-cell embryos cleaved by 30 hpi $(96.3 \pm 1.6 \%)$ had a nucleus in each blastomere. These proportions in the 3-, 4- and $>4$ cell embryos cleaved by $30 \mathrm{hpi}$, however, were significantly lower
$(12.2 \pm 5.3,52.8 \pm 23.4$ and $25.0 \pm 12.4 \%$, respectively) than in the 2-cell embryos. In the 3-, 4- and $>4$-cell embryos, a higher portion of abnormally cleaved embryos contained at least one anuclear blastomere.

The developmental competence of the embryos is shown in Table 3. Two-cell embryos that cleaved by 30 hpi developed to the blastocyst stage at a significantly higher rate $(68.2 \pm 6.3 \%)$ than the 4- and >4-cell embryos ( $46.3 \pm 11.4$ and $42.6 \pm 6.3 \%$, respectively) that cleaved by 30 hpi. Blastocysts generated from the 2-cell embryos also had significantly higher numbers of cells (37.3 \pm 1.9$)$ than those of the 3-, 4- and >4-cell embryos (27.8 \pm 2.7, $29.4 \pm 5.0$ and $23.6 \pm 2.8$, respectively). However, the rate of blastocyst formation from the 3-cell embryos was surprisingly high (65.3 \pm $7.7 \%$ ) and did not differ significantly from that of the 2-cell embryos. Nevertheless, the number of cells in blastocysts generated from the 3-cell embryos $(27.8 \pm 2.7)$ was significantly lower than in blastocysts from the 2-cell embryos. 
Table 4. Effects of evenness of the first cleavage on developmental competence of in vitro produced embryos in pigs

\begin{tabular}{ccrc}
\hline $\begin{array}{c}\text { Blastomere size at } \\
\text { the 2-cell stage }\end{array}$ & No. of embryos examined & Blastocyst (\%) & No. of cells \\
\hline $\begin{array}{c}\text { Even } \\
\text { Uneven }\end{array}$ & 171 & $117(68.4 \pm 4.5)$ & $40.6 \pm 2.0^{\mathrm{a}}$ \\
\hline
\end{tabular}

${ }^{c}$ Embryos at the 2-cell stage were collected at $30 \mathrm{~h}$ post-insemination and classified. 'Evenly cleaved 2-cell embryos were defined as 2-cell embryos in which the smaller blastomeres occupied about $45-50 \%$ of the total cytoplasmic part. Unevenly cleaved 2-cell embryos were defined as 2-cell embryos in which the smaller blastomeres occupied about $36-40 \%$ of the total cytoplasmic part. ${ }^{\text {a, b }}$ Values with different superscripts within a column are significantly different $(\mathrm{P}<0.05)$. Seven replicated trials were carried out.

Table 5. Effects of timing of the second mitotic cleavage on developmental competence of in vitro produced embryos in pigs

\begin{tabular}{cccc}
\hline $\begin{array}{c}\text { Onset of second cleavage } \\
\text { (h after the first cleavage) }^{\mathrm{c}}\end{array}$ & No. of embryos examined & Blastocyst (\%) & No. of cells \\
\hline $6+$ & 33 & $24(72.7 \pm 8.1)^{\mathrm{a}}$ & $40.9 \pm 3.9^{\mathrm{a}}$ \\
$12^{\mathrm{a}}$ & 58 & $47(81.0 \pm 5.4)^{\mathrm{a}}$ & $43.1 \pm 3.3^{\mathrm{a}}$ \\
$18^{+}$ & 18 & $13(72.2 \pm 14.7)^{\mathrm{a}}$ & $36.2 \pm 5.0^{\mathrm{a}}$ \\
$18-$ & 29 & $14(48.3 \pm 5.8)^{\mathrm{b}}$ & $22.5 \pm 2.9^{\mathrm{b}}$ \\
\hline
\end{tabular}

a, b Values with different superscripts within a column are significantly different $(\mathrm{P}<0.05)$. ${ }^{\mathrm{c}}$ Evenly cleaved 2cell embryos by $30 \mathrm{~h}$ post-insemination (hpi) were subsequently cultured. Embryos that showed subsequent cleavage by 36, 42 or 48 hpi $\left(6+, 12+\right.$ and $18^{+}$, respectively) or had not cleaved by 48 hpi (18-) were selected and further cultured until Day 6. Five replicated trials were carried out.

\section{Experiment 4}

Although the rates of blastocyst formation from embryos that cleaved evenly and unevenly by 30 hpi did not differ significantly, the total number of cells in blastocysts from evenly cleaved embryos $(40.6 \pm 2.0)$ was significantly higher than that in blastocysts from unevenly cleaved embryos (33.2 \pm 2.9 ; Table 4$)$.

\section{Experiment 5}

The result indicated that 30-h evenly cleaved 2-cell embryos with subsequent cleavage had a significantly greater chance of developing to blastocysts than those without subsequent cleavage within $48 \mathrm{~h}$ of culture (Table 5). Blastocyst formation rates from the $6+, 12+$ and $18+$ groups were significantly higher $(72.7 \pm 8.1$, $81.0 \pm 5.4$ and $72.2 \pm 14.7 \%$, respectively) than that from the $18-$ group $(48.3 \pm 5.8 \%)$. The total numbers of cells in blastocysts derived from the $6+, 12+$ and $18+$ groups $(40.9 \pm 3.9,43.1 \pm 3.3$ and $36.2 \pm 5.0$, respectively) were significantly higher than that from the 18- group $(22.5 \pm 2.9)$. There was no difference between the $6+, 12+$ and $18+$ groups in the blastocyst formation rates and cell numbers.

\section{Discussion}

Our data confirmed the results of a previous study [13] on the relationship between early timing of the first cleavage and high developmental competence of IVP porcine embryos. In the present study, we found that the timing of the first cleavage had a great effect on the developmental competence of IVP porcine embryos and the quality of blastocysts (Table 1). The embryos that had cleaved by 30 hpi had a significantly higher rate of blastocyst formation than those that cleaved between 30 and 36 hpi. The quality of the blastocysts derived from the embryos cleaved by 30 hpi was also significantly better than that of the embryos cleaved by 36 hpi. Likewise, embryos in which the first cleavage occurred by 42 hpi or later had very low capacities to develop to the blastocyst stage. Our results are in agreement with previous results reported in cattle [14], humans [15], mice [16] and pigs [13, 17]. The timing of the first cleavage affects embryo development, which is known to be regulated by a specific genetic factor, such as a preimplantation embryo development gene in mice and cattle, influenced by the intrinsic features of the oocytes and spermatozoa or influenced by the culture conditions [28]. In our IVC system, pyruvate and lactate were used in the first IVC medium (IVC-PyrLac) as energy sources for embryos for the first 2 days; for the next 4 days (Day 2 to Day 6), energy was supplied by glucose in the second IVC medium (IVC-Glu). Pyruvate and lactate are among the essential factors that help early-stage IVP porcine embryos overcome the 4-cell block [29-31]. Although a large amount of glucose is utilized by the morula or blastocyst (glucose is very important for blastocyst formation), it is not readily metabolized by porcine embryos before the 8-cell stage [32]. This may suggest that the porcine embryos that underwent the first cleavage earlier had a greater chance to complete the second and third cleavages within 2 days and develop to 8-cell-stage embryos before being transferred to IVC-Glu, which is a better medium than IVC-PyrLac for development beyond the 8-cell stage. The embryos that underwent the 
first cleavage later, in contrast, might have been arrested at the 2- to 4-cell stages when cultured in IVC-PyrLac. When those embryos were transferred to IVC-Glu, they had only a small chance to develop to blastocysts because this medium is not very suitable for the development of 2- to 4-cell embryos.

It must be noted, however, that the timing of first cleavage in IVP porcine embryos in our study was different from that recorded in the report of Booth et al. [13]; in their report, the timing of the first embryonic cleavage was found to occur at $21 \mathrm{hpi}$. Nevertheless, in our study, the first cleavages occurred at $24 \mathrm{hpi}$, and the rate of cleaved embryos was very low (5.1\%) at this time. Most of the IVP porcine embryos had cleaved by $30 \mathrm{hpi}$. The rate of newly cleaved embryos gradually decreased after 30 hpi (Fig. 2B). By 48 hpi, a total of $62.4 \%$ of the embryos had undergone the first cleavage. The reason for this discrepancy between the two studies is not yet clear. One possible reason may be the different media used for embryo culture between the two studies. Culture media have been proven to affect the timing of the first cleavage as well as gene expression in embryos [33, 34]. Another study showed that modifications of amino acid composition alter the proportion of bovine IVP embryos that reached the 8-cell stage by 72 hpi [35]. Booth et al. [13] used NCSU-23 supplemented with amino acids for embryo culture with an amino acid composition that differed from ours, and this may be suggested as the cause of the difference in the onset of the first cleavage between the two studies.

Using the in vitro time-lapse system, Mateusen et al. [17] showed that in vivo fertilized porcine embryos that reached the blastocyst stage cleaved faster than embryos whose development ceased at the morula stage. Our results for in vitro produced porcine embryos confirmed the results for in vivo produced embryos: The embryos that underwent the second cleavage within $18 \mathrm{~h}$ after the first cleavage had higher competence compared with the embryos that did not cleave for the second time within the next 18 h. Two-cell embryos that cleaved within $30 \mathrm{~h}$ and had subsequent cleavages within 6 to $18 \mathrm{~h}$ of the first one had greater potential to develop to blastocysts than those without subsequent cleavages within $18 \mathrm{~h}$. The blastocysts derived from these continuously cleaved embryos were also of higher quality (i.e., contained more cells) than those from discontinuously cleaved embryos. However, the timing of the subsequent cleavage (from 6 to $18 \mathrm{~h}$ ) did not have any effect on blastocyst formation. This result is different from previous observations in cattle embryos, in which the length of the second embryonic cell cycle was found to correlate with the developmental competence to the blastocyst stage [36]. Our data suggest clearly that, for early selection of high quality IVP embryos, careful investigation should be made for subsequent cleavages after the 2-cell stage.

During embryo culture, an abnormal cleavage pattern may occur at the first embryonic cell division, resulting in embryos with unusually high numbers of blastomeres and abnormal chromosome numbers [22, 23]. Abnormal cleavage pattern is believed to have a great influence on development of IVP porcine embryos [37]; however, it has not been studied substantially in this species yet. Therefore, we investigated the number of blastomeres and presence/absence of their nuclei in embryos at the first cleavage (30 hpi) and its relation with developmental competence. One of the major differences in the manner of cleavage between mammalian embryos and the embryos of most other animals is the marked asynchrony of early cell divisions [38]. Blastomeres of early mammalian embryos do not cleave at the same time. Thus, the number of blastomeres does not increase exponentially from 2 to 4 and from 4 to 8 ; instead, odd numbers representing one bigger cell and two smaller ones frequently occur [39, 40]. This phenomenon in pigs may be accelerated by polyspermy: an oocyte penetrated by two or more sperm would develop to a poly-pronuclear zygote, and the zygote then might directly divide into either a 3- or 4-cell embryo instead of a 2-cell one [39, 40]. We found 3-cell embryos at a proportion of about $16 \%$ among the cleaved embryos by $30 \mathrm{hpi}$, but only $12.2 \%$ of them were normal (i.e., contained a nucleus in each blastomeres; Table 2). A high rate of embryos contained a blastomere(s) without any nucleus. However, $65.3 \%$ of the classified 3-cell embryos developed to blastocysts (Table 3), suggesting that embryos containing anuclear blastomeres can also develop to blastocysts. However, these embryos had lower cell numbers compared with embryos that had normal morphology. This may have resulted from abnormal chromosome numbers, which have been found in polyspermic embryos at high frequencies [22, 23]. Recent research has also shown that most polypronuclear zygotes cleaved to anuclear blastomeres and thus develop to the blastocyst stage with chromosomal abnormalities [39, 40]. Nevertheless, a high proportion of blastocysts generated from polypronuclear zygotes are diploid, suggesting that correction of embryo ploidy can occur during IVC [40, 41].

The developmental stage and cell numbers of embryos at a given time are thought to be linked to embryo viability and the rate of chromosomal abnormalities [20, 21]. In pigs, in vitro-produced 3or 4- and 5- to 8-cell embryos selected at 52 hpi showed greater potential to develop to blastocysts than embryos having 2 or more than 8 blastomeres at this time [21]. In this report, blastocysts derived from 3- or 4- and 5- to 8-cell embryos also had lower frequencies of chromosomal abnormality. The rate of these abnormalities in 2-cell and >8-cell embryos selected at 52 hpi was also reported to be over $80 \%$. The high incidence of chromosomal abnormality has been thought to be caused by the abnormal nuclear status in the embryos before the 2-cell stage; in most cases, those embryos may be generated by polyspermy [39, 40]. We therefore examined the nuclear status and ability to develop to the blastocyst stage in $30 \mathrm{~h}$ cleaved embryos at different cell stages. The results revealed that almost all 2-cell embryos $(96.3 \pm 1.6 \%)$ had the same numbers of blastomeres as nuclei (Table 2). However, only $52.8 \%$ of the 4-cell embryos (embryos with 4 blastomeres), $25.0 \%$ of the $>4$-cell embryos (embryos with more than 4 blastomeres) and $12.2 \%$ of the 3 -cell embryos (embryos with 3 blastomeres) had the same numbers of blastomeres as nuclei. This observation showed that most embryos with abnormal development contained at least one anuclear blastomere, which would not be able to develop but instead would become a dead component of the resultant embryos [40]. Blastocysts derived from 3-, 4- and $>4$-cell embryos had significantly lower numbers of cells than those from 2-cell embryos (Table 3). Our results suggest that selection of embryos with high blastomere numbers at the time of the first cleavage may lead to 
contraselection of oocytes with an abnormal nuclear status and compromised developmental competence. Thus, according to our research, selection of only 2-cell embryos at the appropriate time (by $30 \mathrm{hpi}$ ) would help to select embryos of high quality and also to exclude embryos with nuclear abnormalities.

We found that a number of 2-cell embryos that cleaved by $30 \mathrm{hpi}$ had one blastomere bigger than the other (Table 4). We therefore investigated whether the uneven blastomere size of the embryos had an effect on developmental competence. Comparison of further development of the embryos showed that although the blastocyst rates from evenly and unevenly cleaved 2-cell embryos did not differ, the blastocysts derived from evenly cleaved embryos were of significantly higher quality than those from unevenly cleaved embryos. Uneven embryo cleavage is also found in humans, and such embryos have lower implantation and pregnancy rates than those of evenly cleaved embryos [18]. This suggested that the choice of evenly cleaved porcine embryos for ET should give a higher priority than that of unevenly cleaved 2-cell embryos.

In our study, we found that the timing, pattern and evenness of the first cleavage and the onset of the second cleavage influenced developmental competence of IVP embryos. However, the embryos were regrouped and cultured separately according to small groups in this study. Thus, cooperative interactions among the embryos of the same groups might also contribute partly to the influences, since preimplantation embryos are capable of promoting development if they are allowed to develop close to one another in an autocrine/paracrine manner [42].

In conclusion, the timing of the first cleavage, cleavage pattern, cleavage evenness and occurrence of subsequent cleavages affected the developmental competence of IVP porcine embryos and the quality of the resultant blastocysts. These criteria could be used to select high-quality embryos in the early stages of their development. The evenly cleaved 2-cell embryos that we evaluated by 30 hpi showed excellent potential to develop to blastocysts. These embryos should be the first priority in selection of good embryos for ET.

\section{Acknowledgments}

The authors would like to thank Ms T Aoki and Ms C Terui for technical assistance. This work is supported by the VAST-JSPS project.

\section{References}

1. Mattioli M, Bacci ML, Galeati G, Seren E. Developmental competence of pig oocytes matured and fertilized in vitro. Theriogenology 1989; 31: 1201-1207.

2. Yoshida M, Ishizaki Y, Kawagishi H. Blastocyst formation by pig embryos resulting from in vitro fertilization of oocytes matured in vitro. J Reprod Fertil 1990; 88: 1-8.

3. Yoshida M, Mizoguchi Y, Ishigaki K, Kojima T, Nagai T. Birth of piglets derived from in vitro fertilization of pig oocytes matured in vitro. Theriogenology 1993; 39: 13031311.

4. Funahashi H, Kim NH, Stumpf TT, Cantley TC, Day BN. Presence of organic osmolytes in maturation medium enhances cytoplasmic maturation of porcine oocytes. Biol Reprod 1996; 54: 1412-1419.

5. Funahashi H, Cantley TC, Day BN. Synchronization of meiosis in porcine oocytes by exposure to dibutyryl cyclic adenosine monophosphate improves developmental competence following in vitro fertilization. Biol Reprod 1997; 57: 49-53.

6. Abeydeera LR, Johnson LA, Welch GR, Wang WH, Bosquest AC, Cantley TC, Rieke
A, Day BN. Birth of piglets preselected for gender following in vitro fertilization of in vitro matured pig oocytes by $\mathrm{X}$ and $\mathrm{Y}$ bearing spermatozoa stored by high speed flow cytometry. Theriogenology 1998; 50: 981-988.

7. Marchal R, Feugang JM, Perreau C, Venturi E, Terqui M, Mermillod P. Meiotic and developmental competence of prepubertal and adult swine oocytes. Theriogenology 2001; 56: 17-29.

8. Kikuchi K, Onishi A, Kashiwazaki N, Iwamoto M, Noguchi J, Kaneko H, Akita T, Nagai T. Successful piglet production after transfer of blastocysts produced by a modified in vitro system. Biol Reprod 2002; 66: 1033-1041.

9. Yoshioka K, Suzuki C, Itoh S, Kikuchi K, Iwamura S, Rodriguez-Martinez H. Production of piglets derived from in vitro-produced blastocysts fertilized and cultured in chemically defined media: effects of theophylline, adenosine, and cysteine during in vitro fertilization. Biol Reprod 2003; 69: 2092-2099.

10. Kikuchi K, Kashiwazaki N, Noguchi J, Shimada A, Takahashi R, Hirabayashi M, Shino M, Ueda M, Kaneko H. Developmental competence, after transfer to recipients, of porcine matured, fertilized, and cultured in vitro. Biol Reprod 1999; 60: 336-340.

11. Nagai T, Funahashi H, Yoshioka K, Kikuchi K. Up date of in vitro production of porcine embryos. Front Biosci 2006; 11: 2565-2573.

12. Lundin K, Bergh C, Hardarson T. Early embryo cleavage is a strong indicator of embryo quality in human IVF. Hum Reprod 2001; 16: 2652-2657.

13. Booth PJ, Watson TJ, Leese HJ. Prediction of porcine blastocyst formation using morphological, kinetic, and amino acid depletion and appearance criteria determined during the early cleavage of in vitro-produced embryos. Biol Reprod 2007; 77: 765-779.

14. Dinnyes A, Lonergan P, Fair T, Boland MP, Yang X. Timing of the first cleavage post insemination affects cryosurvival of in vitro-produced bovine blastocysts. Mol Reprod Dev 1999; 53: 318-324.

15. Fenwick J, Platteau $\mathbf{P}$, Murdoch AP, Herbert $\mathbf{M}$. Time form insemination to first cleavage predicts developmental competence of human preimplantation embryos in vitro. Hum Reprod 2002; 17: 407-412.

16. Kobayashi T, Kato Y, Tsunoda Y. Effect of the timing of the first cleavage on the developmental potential of nuclear-transferred mouse oocytes receiving embryos stem cells. Theriogenology 2004; 62: 854-860.

17. Mateusen B, Van Soom A, Maes DGD, Donnay I, Duchateau L, Lequarre AS. Porcine embryo development and fragmentation and their relation to apoptotic markers: a cinematographic and confocal laser scanning microscopic study. Reproduction 2005; 129: 443-452.

18. Hardarson T, Hanson C, Sjogren A, Lundin K. Human embryos with unevenly sized blastomeres have lower pregnancy and implantation rates: indications for aneuploidy and multinucleation. Hum Reprod 2001; 16: 313-318.

19. Holte J, Berglund L, Milton K, Garello C, Gennarelli G, Revelli A, Bergh T. Construction of an evidence-based integrated morphology cleavage embryo score for implantation potential of embryos scored and transferred on day 2 after oocyte retrieval. Hum Reprod 2007; 22: 548-557.

20. McKierman SH, Bavister BD. Fertilization and early embryology: Timing of development is a critical parameter for predicting successful embryogenesis. Hum Reprod 1994; 9: 2123-2129.

21. Ulloa Ulloa CM, Yoshizawa M, Komoriya E, Mitsui A, Nagai T, Kikuchi K. The blastocyst production rate and incidence of chromosomal abnormalities by development stage in in vitro produced porcine embryos. J Reprod Dev 2008; 54: 22-29.

22. Kola I, Trounson A, Dawson G, Rogers P. Tripronuclear human oocytes: altered cleavage patterns and subsequent karyotypic analysis of embryos. Biol Reprod 1987; 37 395-401.

23. Somfai T, Inaba Y, Aikawa Y, Ohtake M, Kobayashi S, Konishi K, Imai K. Relationship between the length of cell cycles, cleavage pattern and developmental competence in bovine embryos generated by in vitro fertilization or parthenogenesis. J Reprod Dev 2010; 56: 200-207.

24. Petters RM, Wells KD. Culture of pig embryos. J Reprod Fert Suppl 1993; 48: 61-73.

25. Suzuki K, Asano A, Eriksson B, Niwa K, Nagai T, Rodriguez-Martinez H. Capacitation status and in vitro fertility of boar spermatozoa: effects of seminal plasma, cumulus-oocyte-complexes-conditioned medium and hyaluronan. Int J Androl 2002; 25: 84 93.

26. Kikuchi K, Nagai T, Ikeda H, Kashiwazaki N, Noguchi J, Shimada A, Soloy E, Kaneko H. Cryopreservation and ensuing in vitro fertilization ability of boar spermatozoa from epididymides stored at 4 C. Theriogenology 1998; 50: 615-623.

27. Nagai T, Takahashi T, Masuda H, Shioya Y, Kuwayama M, Fukushima M, Iwasaki S, Hanada A. In-vitro fertilization of pig oocytes by frozen boar spermatozoa. J Reprod Fertil 1988; 84: 585-591.

28. Lechniak D, Pers-Kamczyc E, Pawlak P. Timing of the first zygotic cleavage as a marker of developmental potential of mammalian embryos. Biol Reprod 2008; 8: 23-42.

29. Wright RW Jr. Successful culture in vitro of swine embryos to the blastocyst stage. J Anim Sci 1977; 44: 854-858.

30. Davis DL, Day BN. Cleavage and blastocyst formation by pig eggs in vitro. J Anim Sc 
1978; 46: 1043-1053.

31. Menino AR Jr, Wright RW Jr. Development of one-cell porcine embryos in two culture systems. J Anim Sci 1982; 54: 583-588.

32. Flood MR, Wiebold JL. Glucose metabolism by preimplantation pig embryos. J Reprod Fertil 1988; 84: 7-12.

33. Du ZF, Wales RG. Some effects of genotype and composition of the culture medium on the development of mouse zygotes in vitro. Reprod Fertil Dev 1993; 5: 405-415.

34. Doherty AS, Mann MR, Tremblay KD, Bartolomei MS, Schultz RM. Differential effects of culture on imprinted $\mathrm{H} 19$ expression in the preimplantation mouse embryo. Biol Reprod 2000; 62, 1526-1535.

35. Pinyopummintr T, Bavister BD. Effects of amino acids on in vitro development of cleavage stage bovine embryos in blastocysts. Reprod Fertil Dev 1996; 8: 835-841.

36. Holm P, Shukri NN, Vajta G, Booth P, Bendixen C, Callesen H. Developmental kinetics of the first cell cycles of bovine in vitro produced embryos in relation to their in vitro viability and sex. Theriogenology 1998; 50: 1285-1299.

37. Funahashi H. Polyspermic penetration in porcine IVM-IVF systems. Reprod Fertil Dev 2003; 15: 167-177.
38. Gilbert SF. Chapter 11. The early development of vertebrates: Fish, birds, and mammals. In: Gilbert SF (ed.), Developmental Biology, 6th Edition. Massachusetts: Sinauer Associates Inc. Publishers; 2000: 290-326.

39. Han YM, Wang WH, Abeydeera LR, Petersen AL, Kim JH, Murphy C, Day BN, Prather RS. Pronuclear location before the first cell division determines ploidy of polyspermic pig embryos. Biol Reprod 1999; 61: 1340-1346.

40. Somfai T, Ozawa M, Noguchi J, Kaneko H, Karja NW, Fahrudin M, Nakai M, Maedomari N, Dinnyés A, Nagai T, Kikuchi K. In vitro development of polyspermic porcine oocytes: Relationship between early fragmentation and excessive number of penetrating spermatozoa. Anim Reprod Sci 2008; 107: 131-147.

41. Kikuchi K, Somfai T, Nakai M, Nagai T. Appearance, fate and utilization of abnormal porcine embryos produced by in vitro maturation and fertilization. Soc Reprod Fer til Suppl 2009; 66: 135-147.

42. Paria BC, Dey SK. Preimplantation embryo development in vitro: Cooperative interactions among embryos and role of growth factors. Proc Natl Acad Sci 1990; 87: 47564760 . 